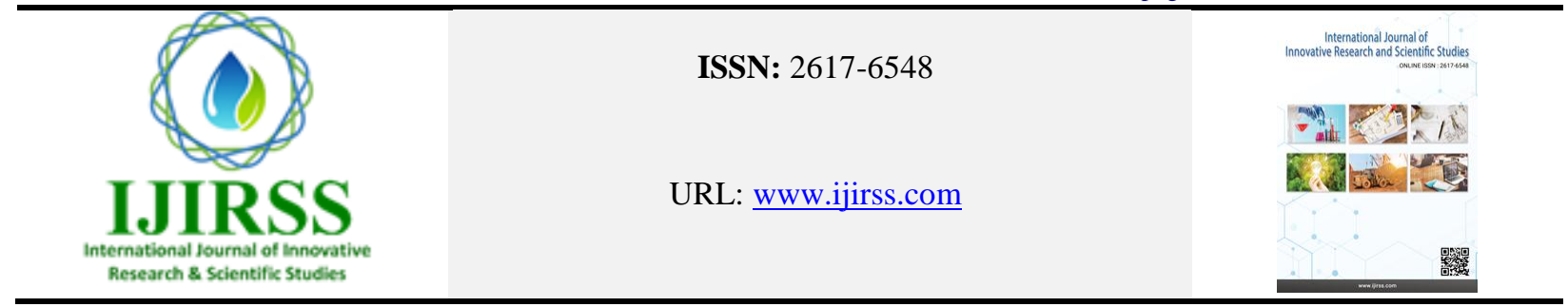

\title{
Assessment of Stand-Alone Photovoltaic System and Mini-Grid Solar System as Solutions to Electrification of Remote Villages in Afghanistan
}

\author{
Mohammad Ali SINA ${ }^{1 *}$, Mohammad Adel ADEEL ${ }^{2}$ \\ 1,2Department of Electric Power Engineering, Technical University of Ghazni, Ghazni city, Afghanistan \\ *Corresponding author: Mohammad Ali SINA (mohd.ali_sina2012@yahoo.com)
}

\begin{abstract}
Afghanistan enjoys huge renewable energy, especially solar resources. Meanwhile, most of the population especially people who live in remote rural areas, still do not have appropriate access to electricity. Poor access to energy has made life more challenging and deprived rustic people from related primary living facilities. To address this grant challenge, considering the high potential of solar energy available in the country, this paper presents a study on design and economic comparison of the two most feasible methods of solar power production for rural areas in Afghanistan. In the first method, a stand-alone Solar Photovoltaic (PV) system has individually been considered in every single house of a village. In this way, energy is produced and consumed in each house itself. While in the second method, energy for the whole village is produced by a micro solar power station in a centralized manner and then distributed through a $0.4 \mathrm{kV}$ islanded Mini grid all around the village. The study is carried out through conventional mathematical relations, based on daily energy demand in a rural household. The result indicates that implementation of the second method is not only best affordable but also more viable and will create other socio-economic opportunities.
\end{abstract}

Keywords: Photovoltaic sizing, stand- alone PV system, cost evaluation, energy cost, rural area, electrification methods.

DOI: 10.53894 /ijirss.v4i2.62

Funding: This study received no specific financial support.

History: Received: 25 January 2021/Revised: 1 March 2020/Accepted: 16 March 2021/Published: 30 March 2021

Licensed: This work is licensed under a Creative Commons Attribution 4.0 License (c) EY

Acknowledgement: Authors would like to thank from organizers and committee members of AFGSolar1 conference, for providing the opportunity to share works and knowledge for better solutions of energy problems is Afghanistan. And authors still want to thank from those respectful people of Ghazni who showed patience as interviewees to answer our survey questions. This survey helped them to have a close concept from the current home solar power supplying situation for clearly stating the problem.

Competing Interests: The authors declare that they have no conflict of interests.

Transparency: The authors confirm that the manuscript is an honest, accurate, and transparent account of the study was reported; that no vital features of the study have been omitted; and that any discrepancies from the study as planned have been explained.

Ethical: This study follows all ethical practices during writing.

\section{Introduction}

Afghanistan is a mountainous and landlocked country located in south-central Asia. The total population of the country in 2020 was 32.9 million people which 23.4 million $(71.13 \%)$ of them live in rural areas [1]. Due to several decades of political conflict and civil war in this country, energy sectors and infrastructures have been widely damaged and dropped behind. Currently, despite high energy resources, especially renewable energy potential available, the country depends heavily on imported electricity. Besides the importing power and somewhat domestic production, the supply is insufficient 
to cover the demand. The electricity demand in the country is more than $2500 \mathrm{MW}$, while the supply by early 2020 was reported $1015 \mathrm{MW}$ as imported power from neighboring countries, and $628 \mathrm{MW}$ domestic production [2]. On the other hand, considering Afghanistan's present and future power system plan [3] we can see that wide part of the country consisting of several hundreds of scattered villages are located far away from the transmission system, and due to low population density and considerable distance from the transmission route, seems unfeasible to be connected with the national electrical grid even in far future. However, most of the households in rural areas currently use PV technology but with very low power output because of economic limitations. A report by National Statistic Information and Authority NSIA [4] pointing out an increasing poverty level stated that $54.5 \%$ of the country's population were facing adversity of poverty. Currently, according to our survey, $93 \%$ of rural households in Ghazni province use only a single PV panel and a small capacity battery storage. This solar home system (SHS) is able only to provide tiny amount of energy just to enlighten a few lamps in limited hours during the night. Due to unsuitably configurations and clumsy operations, this approach is not only very limited but also has a very short useful life, and can't provide energy to other home appliances such as refrigerator, laundry service, TV and etc. Luckily, there is large amount of solar energy potential available in the country. On average, 300 sunny days per year and a total $222.8 \mathrm{GW}$ feasible amount of solar potential has been estimated in Afghanistan [5]. On the other hand, plenty of free-cost land also can be provided in rural areas. According to Ludin, et al. [6] using only $2 \%$ of land in Afghanistan we can produce about 23.576 GW power. Moreover, in Shoaib and Ariaratnam [7] a study of socio-economic impacts of renewable energy projects in Afghanistan shows that enhancing energy access can affect life quality and business, and improve the rural economy. In this paper the authors examined the socio-economic effects of renewable energy projects for cities and communities of Afghanistan. They suggested that these projects will improve social and economic conditions and also create job opportunities.In Sadiqi, et al. [8] the author studied rural electrification to determine the most economically optimal combination of renewables in two scenarios. First, a combination of renewables with battery bank and second the combination of renewables with diesel generator. Finally, he resulted that, the second scenario is a more cost-effective alternative because of its lower cost of energy. In addition, a feasibility study of solar energy in South Asia, including Afghanistan, states that solar renewable energy is more economic and feasible for the population who are living in rural and other areas that are not connected to the national grid [9].

A research on solar electrification of a remote villages in Iran also has shown that this method although has high primary investment cost, the unit cost is lower than other types of power plants [10]. Another study on a stand-alone PV system which was designed and cost estimated for a village in Yemen, concluded that the PV systems have high initial cost but low operating cost and is beneficial for remote areas [11]. According to Jahangiri, et al. [12] the development of renewable energy obtained from solar and wind potential improve people's life and brings economic growth.

Now, considering the current situation of rural electrification, this paper presents the design and cost estimation of the two most feasible methods of remote villages solar powering in Afghanistan. In the first method, a Stand-alone Photovoltaic system, in which the energy is produced and consumed in every single house of the village, and in the second method, energy for the whole village is produced in a centralized manner by a Micro Solar Power Station, and then distributed through a $0.4 \mathrm{kV}$ islanded Mini grid all around the village. This study aims to find out a better and considering the current economic limitations, a more affordable solar powering approach; in order to increase the level of electricity access in rural areas of Afghanistan, and also to encourage private investors to look at this problem as an opportunity.

\section{Methodology}

The power ratings of most necessary home electrical appliances and their operating time during the day were first itemized to obtain the total Watt-hour energy demand per day. The results were used to determine the proposed photovoltaic system components by existing mathematical relations. Then, based on the present cost of Solar PV system components from some reliable sources, the initial cost of the project was calculated. Finally, through annualized capital cost, the cost of energy was determined for each of these two methods and they were compared from a socio-economic point of view. It should be noted that for better stating the problem from a close environment, through distributing online questionnaire consisting total 15 questions, we asked people living in Ghazni province to give information about the current power supplying method of their houses, the ratings of power production and consumption components they are using, and the level of their satisfaction from their present solar home system (SHS). The feedbacks from total 137 respondents have helped us only to state the problem more accurately.

\subsection{Case study area}

Generally in the country, most of the villages are composed of grouped houses collected together. The design is focusing on JoyeNow village of Jaghori district in Ghazni province. This village is located at $67^{\circ} 28^{\prime} 57^{\prime \prime}$ longtitude, and $33^{\circ} 07^{\prime} 57^{\prime \prime}$ altitude. Most of villages in Jaghori district, cosists of 10 to 50 adjacent houses. The village which is selected as a case study area, is composed of 20 houses located in somewhat circular shaped area which is appropriate to locate solar micro power station at the center.

\subsubsection{The first method (Stand-alone Solar Home System)}

In the first method we consider a single household power supply by a stand-alone solar photovoltaic system.

\section{i- Determining the energy consumption demand}

The first step for designing a Stand-alone Solar Home System is to determine the required energy [13]. Table 1, represents the electrical appliances needed in a home with their wattage and their time of operation. 
Table-1.

The rated power and time of operation of most necessary home electrical in a single household.

\begin{tabular}{c|l|c|c|c|c}
\hline No & \multicolumn{1}{|c|}{ Appliance } & Quantity & $\begin{array}{c}\text { Power } \\
(\mathbf{w})\end{array}$ & $\begin{array}{c}\text { Daily use } \\
\text { (h/day) }\end{array}$ & $\begin{array}{c}\text { Daily energy consumption } \\
\text { (Wh) }\end{array}$ \\
\hline $\mathbf{1}$ & LED lamp & 8 & 10 & 5 & 400 \\
\hline $\mathbf{2}$ & TV & 1 & 100 & 8 & 800 \\
\hline $\mathbf{3}$ & PC & 1 & 80 & 4 & 320 \\
\hline $\mathbf{4}$ & Mobile & 3 & 10 & 3 & 90 \\
\hline $\mathbf{5}$ & Water pump & 1 & 1500 & 1.2 & 1800 \\
\hline $\mathbf{6}$ & Refrigerator & 1 & 200 & 8 & 720 \\
\hline $\mathbf{7}$ & Laundry Machine & 1 & 1000 & $0.72 *$ & 220 \\
\hline $\mathbf{8}$ & Other use & 1 & 110 & 2 & 5950 Wh/day/house \\
\hline
\end{tabular}

\section{ii- Sizing of the PV array}

Power required from PV modules can be found according to Equation 1.

$$
P_{P V \text { array }}=\frac{E_{l}}{\rho_{v} \cdot \rho_{\text {inv }} \cdot P S H} \cdot S_{f}
$$

Where $\rho_{v}, \rho_{i n v}$ are the efficiency of the charge controller and inverter respectively and the PSH shows the peak sunshine hours which for the target area is $5.25 \mathrm{kWh} / \mathrm{m}^{2} /$ day [12]. Considering the efficiency of inverter as $92 \%$ and for charge controller $90 \%$, and $S_{f}$ which is the safety factor equal to $5 \%$ we have:

$$
P_{P V \text { array }}=\frac{5950}{0.92 \cdot 0.9 \cdot 5.25} \cdot 1.05=1437.2 \mathrm{~W}
$$

The peak load DC current:

$$
\begin{gathered}
I_{d c}=\frac{\text { Ppv array }}{\text { system DC voltage }}=\frac{P_{p v \text { array }}}{V_{d c}} \\
I_{d c}=\frac{1437.2}{24}=59.9 \mathrm{~A}
\end{gathered}
$$

The PV module of $(A S 6 M 30-240,240 \mathrm{Wp}, V o c=34.5 \mathrm{~V} . \mathrm{Isc}=8.93 \mathrm{~A}, \mathrm{Vmpp}=27.7 \mathrm{~V}$ and current at $\operatorname{Impp}=8.32 \mathrm{~A})$ is selected. The maximum power will be: $230.5 \mathrm{~W}$.

\section{iii- Determining the PV module output power considering the affecting factors}

The affecting factor which influences the output of the PV modules are:

a- Manufacturer output error $\left(F_{\text {manf }}\right)$ : The output power of PV modules in Watts approximately considered $\pm 5 \%$ which is defined in $25^{\circ} \mathrm{C}$ for the cells. In our case according to the data sheet of chosen solar, $\mathrm{F}_{\text {manf }}$ is given $0 \div+3 \%$, so we consider the $\mathrm{F}_{\text {manf }}=0$. Thus the module output will receive no effect of manufacturing error and remains constant 240 W.

b- Pollution factor $\left(F_{\text {dirt }}\right)$ : The output of a PV module will reduce due to dirt on it. In designing the PV array the amount of this reduction is considered by this factor. This factor depends on the environment and climate of the area where the modules are mounted. The $\mathrm{F}_{\text {dirt }}$ is considered to be $3 \%$, because in the village where the project is located, the level of air pollution is much lower than the cities; so the module output will be: $W p=240-3 \% \times(240)=232.8 W$

c- Temperature effect factor $\left(F_{\text {temp }}\right)$ : This factor is calculated by Equation 3 .

$$
F_{\text {temp }}=1-(\gamma \times(\text { Tcell. eff }- \text { Tstc }))
$$

Where $\gamma$ is the energy temperature factor which shows that for every $\left({ }^{\circ} \mathrm{C}\right)$ growth of temperature higher than $25^{\circ} \mathrm{C}$, how much the output power of the PV module decreases [14]. In our case for the selected PV module the $\gamma$ is $\left(0.41 \% /{ }^{\circ} \mathrm{C}\right)$ [15]. $T_{\text {stc }}$ is the temperature in standard test condition and Tcell. eff according to the AS4059.2 standard, is the average temperature of the module's cells which is calculated by the formula:

$T_{\text {cell eff }}=T_{a \text { day }}+25$, where $\mathrm{T}_{\text {cell eff }}$ is the average effective daily temperature of cells in ${ }^{\circ} \mathrm{C}$, and $\mathrm{T}_{\mathrm{a} \text { day }}$ is the average daily temperature in specific month in $\left({ }^{\circ} \mathrm{C}\right)[13]$.

$\mathrm{T}_{\mathrm{aday}}=27^{\circ} \mathrm{C}$ in hottest month of the year for the targeted area, from Weahter and Climate Website [16]. So, $T_{\text {celleff }}=$ $27+25=52{ }^{\circ} \mathrm{C}$. And $\gamma$ for the given modules is defined $-0.041 \%$ by the manufacturer, and $T s t c=25^{\circ} \mathrm{C}$ in standard test condition. Therefore, using the given formula, we obtain the $F_{\text {temp }}=0.877$.

Hence with considering the affecting factors, the output of $240 \mathrm{Wp}$ of the selected module will decrease to $209.89 \mathrm{~W}$.

\section{iv- Calculation of the number of PV modules}

For a Stand-alone Solar Home System, it is necessary to define the PV modules that can satisfy the load and also the battery charging power. These modules have to be connected in such a way that can meet the necessary current and voltage of the system. Hence the following conditions has to be accomplished [13]:

1- The number of the series modules is equal to system DC voltage divided by the module rated voltage: 


$$
N_{S}=\frac{V_{D C}}{V_{r}}=\frac{24}{30.3}=0.79 \approx 1 \text { Module in series }
$$

2- The number of parallel connected modules is found by division of the total Solar PV array power by power of one single module and number of modules in series.

$$
N_{p}=\frac{P_{P V \text { array }}}{N_{m} \cdot P_{\text {module }}}=\frac{1437.2}{1 \cdot 209.89}=6.84 \approx 7 \text { Modules } \text { in parallel }
$$

Then the number of total needed modules $=$ Ns $x$ Np.

$N_{\text {total modules }}=1 \times 7=7$ Modules. So the total generation at MPP will be: $7 \times 230.5=1.62 \mathrm{~kW}$

The total cost of modules while one module costs $0.21 \$ /$ watt [15] is: $7 \times 240$ watts $\times 0.21 \$ /$ watts $=357 \$$

\section{v- Sizing of the battery bank}

The battery bank size and its capacity must be designed in such a way that in addition to the supplying power in usual daily hours which there is no sun or less sun, it also should be able to supply the loads in case of difficult weather conditions, for certain number of autonomy days. The cloudy days during which the battery bank has to supply the load without being recharged by solar system, is called autonomy days. The approximate capacity of energy storage is obtained from Equation 4 according to Mothilal and Pillai [17].

$$
C_{A h}=\frac{N_{\text {atonomy }} \cdot E_{l}}{\rho_{B} \cdot \rho_{\text {inv }} \cdot V_{B B} \cdot D O D}
$$

Where $\rho_{B}$ and $\rho_{\text {inv }}$ are the efficiencies of the battery and inverter respectively, $\mathrm{V}_{\mathrm{BB}}$ is the voltage of battery bank and DOD is depth of discharge. Considering the meteorological statistics for the targeted area the number of autonomy days ( $N_{\text {atonomy }}$ ) is selected 2 days. Thus the Ampere-hour capacity of the battery bank is:

$$
C_{A h}=\frac{3 \cdot 5950}{0.93 \cdot 0.92 \cdot 12 \cdot 0.75}=1422 \mathrm{Ah}
$$

The battery of (MAXI lead acid $200 \mathrm{Ah}, 12 \mathrm{~V}$ ) is selected.

The number of parallel and series batteries are calculated as follow.

$$
\begin{aligned}
& \text { Number of batteries }=\frac{C_{A h}}{\text { Capacity of one battery }} \\
& \text { Number of batteries }=\frac{1422}{200}=7.108 \text { Batteries } \\
& N_{\text {Series batteries }}=\frac{\text { The system DC voltage }}{\text { Battery rated voltage }}=\frac{24}{12}=2 \text { Batteries } \\
& N_{\text {strings }}=\frac{\text { Number of batteries }}{\text { Number of batteries in series }}=\frac{7.108}{2}=3.55 \cong 4 \text { strings }
\end{aligned}
$$

Thus the total number of batteries are: $2 \times 4=8$ Batteries.

The total cost of batteries used in battery bank while one battery costs $125 \$$, is equal to: $8 \times 125 \$=1000 \$[18]$.

\section{vi- Sizing of the Charge controller}

The charge controller must be capable to handle the maximum load current passing through the controller for unlimited time. Furthermore, it should be able to handle the maximum photovoltaic array current. For this reason, we use the maximum array short circuit amps which is greater than the operating current. It equals to module short circuit current $\mathrm{x}$ number of strings plus a $25 \%$ of this current as a safety margin. Its voltage range should match the PV array output voltage [19].

In our case: $I_{S C \text { array }}=I_{S C \text { module }} x N_{\text {Parallel modules }} x 1.25=8.93 \times 7 \times 1.25=78.13 \mathrm{~A}$

$$
\begin{aligned}
& \text { Max load DC Amp }=\frac{\text { Max generation }}{\text { DC system voltage }} \\
& \text { Max load DC Amp }=\frac{1.62 \mathrm{~kW}}{24}=67.3 \mathrm{~A}
\end{aligned}
$$

So we select SP2480 Charge Controller for 24 V, 80 A. It costs 65 \$, [20].

\section{vii- Sizing of the inverter}

The output power of the inverter must be at least $25-30 \%$ higher than the total load power which simultaneously applied on the inverter [13]. It should be noted that the performance of inverter from the losses point of view is not constant with the power. In order to avoid this waste of energy it is better to consider not the peak power of all equipment, but the peak power of simultaneously applied loads. The probable maximum power applied on inverter is 3100 watts.

Considering diversity factor, $D F=1.2$ according to Jiguparmar [21] the applied load on the inverter will be: $3100 / 1.2=2584 \mathrm{~W}$. Thus the minimum capacity of needed inverter is: $P_{\text {inverter }}=1.25 \times$ Peak load $=1.25 \times 2584=3230$ $W$. So the inverter [Grand glow Inverters GS-3.5kW - Single Phase] was selected. This inverter costs 396 \$, [22].

\subsubsection{The Second method (Micro Solar Power Station)}

In the second method it is considered to produce power by a Micro solar plant and distribute through $0.4 \mathrm{kV}$ Mini grid for whole the village to provide the same level of electrification as in first method which discussed formerly. The targeted village is composed of a total 20 households having the same home electrical appliances and the same load character as the 
single household described above. In this case the total load will be: $20 \times 3.100=62 \mathrm{~kW}$ and daily required energy is $20 \times 5.950=119 \mathrm{kWh} /$ day. Obviously in this case we have to build an electrical grid to distribute the generated electricity among the houses thus; considering $5 \%(5.95 \mathrm{kWh} /$ day) grid loss, the total required energy to be produced is: $124.95 \mathrm{kWh} /$ day.

Following the same design procedure as used in previous method, we will find the size of the PV array and battery bank components for whole the village as briefed in (Tables 3 - 5). In this method (Micro solar power station), due to heavy load and high DC current, we select the system DC voltage bit higher (180 volt) to reduce the DC current in optimum value, hence the sizes of inverter and controller recalculated as follow:

\section{i- $\quad$ Sizing of the Charge controller for micro solar plant}

In this case: $I_{S C \text { array }}=I_{S C \text { module }} x N_{\text {Parallel modules }} \times 1.25=8.93 \times 24 \times 1.25=268 \mathrm{~A}$. So we select five [SP $192,60 \mathrm{~A}$ Charge Controller for 192 VDC, $60 \mathrm{~A}]$ in parallel combination. It costs $184 \$$ each [19]. The total cost will be: $5 \times 184=$ $920 \$$.

\section{ii- $\quad$ Sizing of the inverter for micro solar plant}

As the electrical network is supplied by AC $0.4 \mathrm{kV}$ voltage, then it is necessary to use inverter for converting the DC voltage into AC. The maximum estimated load plus grid loss is $65.1 \mathrm{~kW}$. The diversity factor of residential load common distribution board is $\mathrm{DF}=2$ [21] so the applied load on inverter will be $32.55 \mathrm{~kW}$. The required size of inverter will be: $P_{\text {Inverter }}=1.25 \times 32.55=41 \mathrm{~kW}$

Three inverters of [Grand glow-15kW 192 VDC input and 3 phase 400 VAC output] with total $45 \mathrm{~kW}$ rated power is selected. It costs 1320 \$ each [21].

\subsection{Energy Cost Estimation}

For calculation of the energy cost first it is necessary to calculate the annualized total cost of each system. Because each component has different life span as in Table 2, so it is needed to calculate the annualized capital cost separately. The annual capital cost of each component is calculated using Equation 7.

$$
A_{n}=P\left[\frac{d(1+d)^{T}}{(1+d)^{T}-1}\right]
$$

Where in Equation 7, the A is the annualized capital cost, (d) is the inflation rate considered equal to $5 \%$. T is the total life of the components in year, and $\mathrm{P}$ is the present cumulative value of the component.

Table-2.

The life spans of the system components based on manufacturer report.

\begin{tabular}{l|c}
\hline Component & Life span T (Year) \\
\hline PV modules & 20 \\
\hline Batteries & 7 \\
\hline Inverter & 15 \\
\hline Charge controller & 15 \\
\hline
\end{tabular}

Once the annualized capital cost of each component $\left(A_{n}\right)$ is calculated, the total annualized capital cost is then calculated by summing the (A) for all the components. The cost of energy can be calculated by dividing the total annualized cost by the yearly produced energy of the system [23]. The results are available in Tables 7 and 8).

\section{Results}

The results obtained from various steps and final answers of all above calculations are tabulated as follows. Table 3 presents the detailed result of PV array sizing for a single house and 20 houses in both the methods. As the table illustrates, the system DC voltage is selected 24 Volts and 180 Volts in first and second method respectively. The number of necessary PV modules are calculated to be 7 parallel modules for the first, and 144 modules combined in 24 strings of 6 modules in series for the second method.

Table-3.

The results of the PV array design of both the methods

\begin{tabular}{|c|c|c|c|c|c|c|c|c|c|}
\hline \multirow[b]{2}{*}{ 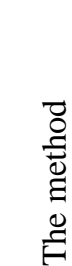 } & \multirow{2}{*}{ 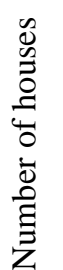 } & \multicolumn{8}{|c|}{ PV array sizing results } \\
\hline & & $\begin{array}{c}P_{P V} \text { array } \\
(\mathrm{W})\end{array}$ & $\mathrm{I}_{\mathrm{DC}}(\mathrm{A})$ & $\begin{array}{l}\text { System DC } \\
\text { voltage (V) }\end{array}$ & $\begin{array}{l}\text { Calculated } \\
\text { Number of } \\
\text { modules in } \\
\text { series }\end{array}$ & $\begin{array}{c}\text { selected } \\
\text { number of } \\
\text { modules in } \\
\text { series }\end{array}$ & $\begin{array}{c}\text { Calculated } \\
\text { number of } \\
\text { string }\end{array}$ & $\begin{array}{l}\text { Selected } \\
\text { Number } \\
\text { of strings }\end{array}$ & $\begin{array}{c}\text { Total } \\
\text { needed } \\
\text { Modules }\end{array}$ \\
\hline $1^{\text {st }}$ & 1 & 1437.2 & 59.9 & 24 & 0.79 & 1 & 6.85 & 7 & 7 \\
\hline $2^{\text {nd }}$ & 20 & 30181.2 & 168 & 180 & 5.94 & 6 & 23.97 & 24 & 144 \\
\hline
\end{tabular}


Table 4 indicates the details of battery bank sizing. As it is clear from the table, the type of batteries, number of autonomy days and depth of discharge (DOD) for both the methods have been considered the same. The total number of necessary battery for $1^{\text {st }}$ and $2^{\text {nd }}$ methods comes out to be 12 and 225 batteries respectively.

Table-4.

The results of the Battery sizing for both the method

\begin{tabular}{|c|c|c|c|c|c|c|c|c|c|c|}
\hline \multirow[b]{2}{*}{ 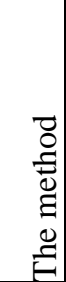 } & \multirow{2}{*}{ 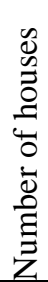 } & \multicolumn{9}{|c|}{ Battery sizing results } \\
\hline & & DOD & $\begin{array}{c}\text { Number of } \\
\text { Autonomy } \\
\text { days }\end{array}$ & $\begin{array}{c}\text { System } \\
\text { DC } \\
\text { voltage } \\
\text { (V) }\end{array}$ & $\begin{array}{c}\text { Required } \\
\text { capacity } \\
\mathrm{C}_{\mathrm{Ah}} \\
\text { (Ah) }\end{array}$ & $\begin{array}{c}\text { Selected } \\
\text { Battery } \\
\text { capacity } \\
\text { (Ah) }\end{array}$ & $\begin{array}{c}\text { Battery } \\
\text { voltage } \\
\text { (V) }\end{array}$ & $\begin{array}{c}\text { Number } \\
\text { of } \\
\text { Battery } \\
\text { in series }\end{array}$ & $\begin{array}{c}\text { Number } \\
\text { of } \\
\text { strings }\end{array}$ & $\begin{array}{c}\text { Total } \\
\text { Number } \\
\text { of } \\
\text { Batteries }\end{array}$ \\
\hline $1^{\text {st }}$ & 1 & 0.75 & 2 & 24 & 1421.7 & 200 & 12 & 2 & 4 & 8 \\
\hline $2^{\text {nd }}$ & 20 & 0.75 & 2 & 180 & 29856.6 & 200 & 12 & 15 & 10 & 150 \\
\hline
\end{tabular}

The cost of the PV system components with respect to their types and quantities have been illustrated in Tables 5 and 6 , for the first and second methods respectively.

Table-5.

The system components and cost estimation of the first method (Stand-alone Solar Home System)

\begin{tabular}{l|l|l|c|c|c}
\hline No & Component & Type & Quantity & $\begin{array}{c}\text { Unit price } \\
\mathbf{( \$ )}\end{array}$ & $\begin{array}{c}\text { Cost per } \\
\text { component } \mathbf{( \$ )}\end{array}$ \\
\hline $\mathbf{1}$ & PV modules & AS 6M 30-240 & 7 & 51 & 357 \\
\hline $\mathbf{2}$ & Batteries & MAXI lead acid 200Ah 12V & 8 & 125 & 1000 \\
\hline $\mathbf{3}$ & Charge controller & SP-24,80 Garnde Solar & 1 & 65 & 65 \\
\hline $\mathbf{4}$ & Inverter & Grand glow 3.5kW 1 Phase & 1 & 396 & 396 \\
\hline $\mathbf{5}$ & Support structure & - & 1 & $135^{*}$ & 135 \\
\hline $\mathbf{6}$ & Switches \& Wiring & - & - & - & $300^{*}$ \\
\hline & Total cost (\$) & & & & 2253 Say 2260 \\
\hline
\end{tabular}

Table-6.

The system components and cost estimation of the second method (Micro solar station).

\begin{tabular}{l|l|l|c|c|c}
\hline No & \multicolumn{1}{|c|}{ Component } & \multicolumn{1}{|c|}{ Type } & Quantity & Unit price (\$) & $\begin{array}{c}\text { Cost per } \\
\text { component }\end{array}$ \\
\hline $\mathbf{1}$ & PV modules & AS 6M 30-240 & 144 & 51 & 7344 \\
\hline $\mathbf{2}$ & Batteries & MAXI lead acid 200Ah 12V & 150 & 125 & 18750 \\
\hline $\mathbf{3}$ & Charge controller & SP-192,60 Garnde Solar & 5 & 184 & 920 \\
\hline $\mathbf{4}$ & Inverter & Grand glow 15kW 3 Phase & 3 & 1320 & 3960 \\
\hline $\mathbf{5}$ & Support structure + & - & 1 & $1800^{*}+800^{*}$ & 2600 \\
\hline $\mathbf{6}$ & Switches \& Wiring & - & - & - & $1500^{*}$ \\
\hline & Total cost (\$) & \multicolumn{3}{|c|}{ Has not been considered } \\
\hline
\end{tabular}

Note: * Approximated values

Table-7.

The energy cost estimation for the first method (Stand-alone Solar home system)

\begin{tabular}{|c|c|c|c|}
\hline Component & $\begin{array}{c}\text { Life span } \\
\text { T (year) }\end{array}$ & $\begin{array}{c}\text { Interest rate } \\
\text { d }(\%)\end{array}$ & $\begin{array}{l}\text { Annualized } \\
\text { capital cost (\$) }\end{array}$ \\
\hline PV modules & 20 & 0.05 & 28.65 \\
\hline Batteries & 7 & 0.05 & 172.82 \\
\hline Charge controller & 15 & 0.05 & 6.26 \\
\hline Inverter & 15 & 0.05 & 38.15 \\
\hline Daily energy produced & & 5.95 & $\mathrm{kWh}$ \\
\hline Annual produced energy & & 2171.75 & $\mathrm{kWh}$ \\
\hline Energy cost & & 0.113 & $\$ / \mathrm{kWh}$ \\
\hline
\end{tabular}


Based on the life span the most important components of the PV system, and considering a 5\% inflation rate ( $\mathrm{d}=5 \%)$, the energy cost has been calculated as previously described in Section 2.2. The results for the first and second methods can be seen in Tables 7 and 8 respectively.

Table-8.

The energy cost estimation for the second method (Micro Solar Station)

\begin{tabular}{|c|c|c|c|}
\hline Component & $\begin{array}{c}\text { Life span } \\
\text { T (year) }\end{array}$ & $\begin{array}{c}\text { Interest rate } \\
\text { d }(\%)\end{array}$ & $\begin{array}{l}\text { Annualized } \\
\text { capital cost }(\$)\end{array}$ \\
\hline PV modules & 20 & 0.05 & 589.30 \\
\hline Batteries & 7 & 0.05 & 3240.37 \\
\hline Charge controller & 15 & 0.05 & 88.63 \\
\hline Inverter & 15 & 0.05 & 381.52 \\
\hline Daily energy produced & & 124.95 & $\mathrm{kWh}$ \\
\hline Annual produced energy & & 45606.75 & $\mathrm{kWh}$ \\
\hline Energy cost & & 0.094 & $\$ / \mathrm{kWh}$ \\
\hline
\end{tabular}

\section{Discussion}

To provide power for the targeted village, we considered two methods. As in the first method, there is no network existing, thus no losses due to the network will occur while in the second method, because the produced energy by Micro solar power station is distributed through a Mini-grid, therefore, the network losses come in to account. Thus, to cover the demand, daily at least $124.95 \mathrm{kWh}$ energy has to be provided. Based on estimated demand values, the size of the PV array, battery bank capacity and ratings of charge controllers and inverters for both intended methods have been calculated accordingly. According to the first method, as indicated in the first row of Table 3 , for each household, a PV array consisting of 7 parallel connected modules of $240 \mathrm{Wp}$ is necessary, which the maximum output DC voltage and current of the array will be $34.5 \mathrm{VDC}$ and $7 \times 8.93=62.5 \mathrm{~A}$. And also as per the first row of Table 4 , for each household according to the first method, a battery bank including 8 batteries of $200 \mathrm{Ah}$ capacity is required. To ascertain this, as per Table 5 the cost will come 2260 \$ on each individual solar home system. With this approach, assuming the same load value and same component characteristics as in the first method, for all 20 households existing in the village totally 140 PV modules and 160 batteries have to be provided, and totally $45200 \$$ has to be spent by whole the village to achieve the targeted level of electricity access. While, as indicated in the second rows of Table 3 and 4, to supply the whole village consisting of 20 households by a Micro solar power station (second method), there has 144 PV modules of $240 \mathrm{Wp}$ and a battery bank including 150 batteries of 200 Ah capacity in 10 strings consisting 15 series 12 volt batteries been estimated. Consequently, according to Table 6 , by this way totally $35100 \$$ is required to be spent. For the proposed micro solar power station, the PV array is a combination of 24 strings having 6 series modules each. So the open circuit output voltage is: $6 \times 34.5=$ 207 VDC, and maximum DC current $=24$ parallel modules $\times 8.93 \mathrm{~A}=214.3 \mathrm{~A}$.

Comparing these two approaches, we can find that the initial cost of the second method (Micro solar power station) without the electrical grid, for whole the village comes lower than the first method by $10100 \$$. Additionally, these two methods have different socio-economic impacts as briefed in advantage and drawback in Tables 9 and 10.

Table-9.

The advantages and drawbacks of the first method (Stand-alone Solar Home System)

Advantages $\quad$ Drawbacks

1. Smaller system, thus doesn't require much maintenance cost.

2. Much modular, thus best matches the demand.

1. Not affordable for most of the families (Due to economic conditions), thus most of poor families are deprived from enough electricity access.

2. Can't have professional and regular maintenance, thus shorted life of system components.

3. Brings independency for each household.

3. Due to lower diversity factor, components of much higher output ratings are required.

4. Higher cost of energy $(\$ / \mathrm{kWh})$

These differences stem from these two facts: First, the specific cost per $\mathrm{kW}$ of many of the system components $e . g$. inverter, charge controller, supports and structures of the solar system with higher output power values, are significantly lower than those for smaller output power values. And second, in the case of higher number of households connected to one distribution board, the higher value of diversity factor occurs in electrical load estimation thus, decreases the requirements of sizing the components.

\section{Conclusion}

To achieve an acceptable level of electricity access by stand-alone solar power system with 2 days backup storage in a rural house, it is necessary to spend at least $2260 \$$, which currently due to unfavorable economic conditions in the country 
it is not applicable for most of the families. To provide this level of electricity access in each house, whole the village totally has to spend $45200 \$$. While by the second method, forgetting about investment on the electrical grid, $35100 \$$ is necessary to build a Micro solar power plant with $33.5 \mathrm{kWp}$ capacity and 2 days backup storage to provide equal amount of power for whole the village as in the previous method. However, to implement the second method we must build a distribution grid, this approach has more other positive socio-economic impacts as described in Table 10. Since the first method due to the economic limitations of the families is not possible, to realize appropriate electricity access in rural areas the second method can be adopted through investing by small private investors.

Table-10.

The advantages and drawbacks of the second method (Micro solar station with mini $0.4 \mathrm{kV}$ grid).

\begin{tabular}{|c|c|}
\hline Advantages & Drawbacks \\
\hline 1. $\quad$ Creates Investment opportunities. & $\begin{array}{l}\text { 1. Requires regular maintenance thus higher maintenance } \\
\text { cost. }\end{array}$ \\
\hline 2. $\quad$ Creates job opportunities. & 2. Needs electrical grid investment. \\
\hline $\begin{array}{l}\text { 3. Extends the life cycle of the equipment due to regular } \\
\text { maintenance. }\end{array}$ & \multirow[t]{4}{*}{ 3. Energy loss in electrical grid. } \\
\hline 4. $\quad$ Provides enough and equal energy accessibility. & \\
\hline $\begin{array}{l}\text { 5. Brings affiliation and cooperation practices between } \\
\text { families living in the village. }\end{array}$ & \\
\hline 6. $\quad$ Lower cost of energy $(\$ / \mathrm{kWh})$ & \\
\hline
\end{tabular}

\section{References}

[1] National Statistic Information and Authority, "NSIA "estimated population of Afghanistan 2020-21. Retrieved from https://www.nsia.gov.af:8080/wp-content/uploads/2020/06/," 2020.

[2] News Report, "Work on 9 power supply projects has been completed. Jomhornews. Retrieved from http://www.jomhornews.com/fa/news/125279/," 2020.

[3] Afghanistan Energy Information Center - AEIC, "Current and future power system up to 2032, Grid Map_ 19 Sept, 2020," 2020.

National Statistic Information and Authority - NSIA, "Afghanistan living condition in 2016," 2018.

MEW Renewable Energy Department, "Renewable energy potential in Afhganistan," 2015.

G. A. Ludin, M. A. Amin, A. Aminzay, and T. Senjyu, "Theoretical potential and utilization of renewable energy in Afghanistan," Aims Energy, vol. 5, pp. 1-19, 2016.

[7] A. Shoaib and S. Ariaratnam, "A study of socioeconomic impacts of renewable energy projects in Afghanistan," Procedia Engineering, vol. 145, pp. 995-1003, 2016.Available at: https://doi.org/10.1016/j.proeng.2016.04.129.

[8] M. Sadiqi, A. Pahwa, and R. D. Miller, "Basic design and cost optimization of a hybrid power system in rural communities in Afghanistan By Mahdi Sadiqi," presented at the In 2012 North American Power Symposium (NAPS), pp. 1-6. IEEE, 2012.

[9] D. Palit, "Solar energy programs for rural electrification: Experiences and lessons from South Asia," Energy for Sustainable Development, vol. 17, pp. 270-279, 2013.Available at: https://doi.org/10.1016/j.esd.2013.01.002.

[10] H. Fayazi and M. B. Mehdi, "Study of electricity supply to remote villages (centered on Kohgiluyeh city) using photovoltaic systems. Retrieved from https://civilica.com/doc/243992," 2015.

[11] A. Q. Al-Shetwi, "Design and economic evaluation of electrification of small villages in rural area in Yemen using stand-alone PV system," International Journal of Renewable Energy Research (IJRER), vol. 6, pp. 289-298, 2016.

[12] M. Jahangiri, A. Haghani, A. Mostafaeipour, A. Khosravi, and H. A. Raeisi, "Assessment of solar-wind power plants in Afghanistan: A review," Renewable and Sustainable Energy Reviews, vol. 99, pp. 169-190, 2019.Available at: https://doi.org/10.1016/j.rser.2018.10.003.

[13] K. Sopian, A. Elbreki, M. Ruslan, E. B. Ali Najah Al-Shamani, M. A. Azher, and D. M. Husam Abdulrasool Hasan, "A standalone photovoltaic system design and sizing: A greenhouse application in sabha city: Case study in Libya," in Proceeding of The 3rd Engineering Science And Technology, 2016.

[14] I. Nezamfanni, "Guide to the design of photovoltaic systems to supply electricity by climate and land use in the Islamic Republic of Iran," 2014.

[15] Solar Panel Datasheet, "Ameri solar, 2020. https://www.enfsolar.com/pv/paneldatasheet/crystalline/7933. [Accessed Nov. 03, 2020]," 2020.

[16] Weahter and Climate Website, "The mean minimum and maximum temperatures over the year in Ghazni, Afghanistan," Weahter and Climate, 2020.

$[17] \quad$ B. S. Mothilal and G. Pillai, "PV microgrid design for rural electrification," Designs, vol. 2, p. 33, 2018.

[19] D. A. Z. Y. Aye Aye Mu, "Design and analysis of solar power system for sinywa village in Mandalay Region. Retrieved from https:// www.researchgate.net/publication/332497235_Design_and_Analysis_of_Solar_Power_System_for_Sinywa_Village in_Mandalay_Region," 2011.

[20] Grande Solar Corp, "Charge controller price," ENF Solar, 2020. Retrieved from https://www.enfsolar.com/pv/chargecontroller-

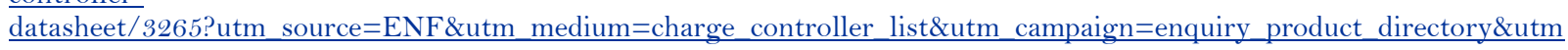
content $=110589$," 2020 .

[21] Jiguparmar, "Demand factor-diversity factor-utilization factor-load factor," Energy Power, EEP Acad. Retrieved from https://electrical-engineering-portal.com/demand-factor-diversity-factor-utilization-factor-load-factor," 2011.

[22] Grand Glow New Energy Technology Co Ltd, "Inverter prices," ENF Solar. Retrieved from https://www.enfsolar.com/pv/inverter-datasheet/12009?utm_source=ENF\&utm," 2020.

[23] S. K. Rajput, "Solar energy fundamentals, economic and energy analysis," 2017. 